\title{
INFORMATION SYSTEMS MANAGEMENT: AN AUSTRALASIAN VIEW OF KEY ISSUES - 1996
}

Graham Pervan, School of Information Systems,

Curtin University of Technology, GPO Box U1987, Perth, WA, 6001, Australia

Email: pervang@cbs.curtin.edu.au

\begin{abstract}
As part of a longitudinal study of key information systems management issues, a survey of Australasia's largest 500 organisations was conducted to identify which issues were perceived by the IS executives as being important, problematic and critical over the next three to five years. The most critical issues were revealed to be a mix of technology management issues (IT infrastructure, communications, disaster recovery), strategic management issues (competitive advantage, IS planning, aligning the IS organisation), people management issues (organisational learning, educating senior management in $I T$ ). systems development and data management issues (effective use of the data resource), and end-user computing. This reflects the need for a balance of business, technical, and people skills in an IS executive. Non-critical issues were mostly related to systems development and the individual technologies which must be integrated and managed to ensure a responsive $\mathrm{IT}$ infrastructure. The study also reveals that some issues are much more important than problematic (disaster recovery, competitive advantage, information architecture, and IS alignment) while others are much more problematic than important (end-user computing, IS role and contribution, and BPR). The former reflects a growing level of knowledge in handling these issues, while the latter reflects a continuing problem with them. The differences between this study and similar studies conducted in 1988 and 1992 show that there is a growing confidence in the IS executive's ability to manage the strategic issues, a continuing concern about providing a responsive $I T$ infrastructure (especially communications), and a continuing concern with educating all 'customers' in the organisation in the effective use of $\mathrm{IT}$, including senior management.
\end{abstract}

\section{INTRODUCTION}

Rapidly changing business environments are challenging information systems (IS) executives as evidenced by the now familiar themes of downsizing, outsourcing, leveraged buyouts, strategic alliances, flexible manufacturing, just-in-time scheduling, globalisation, business process reengineering and total quality management. These environmental changes place demands on IS departments to support product innovation, new production techniques, and changing organisational designs, and provide timely, high-quality information. As a result, the role of IS executives has shifted from merely supporting a technical operation to a strategic role providing information for the organisation to implement strategies and achieve objectives (Galliers et al. 1994). Identifying and handling key issues in the management of information systems is essential for IS executives to support their organisations efficiently and effectively. The investigation of these key issues by researchers serves to enhance understanding of the concerns of IS executives and suggest relevant areas of investigation by IS management researchers. The aims of this study are to:

- determine the IS management issues most important, problematic and critical to Australasian IS executives over the next 3-5 years;

- examine trends in the status of different issues over time;

- inform IS professionals of current and future issues;

- inform IS researchers of relevant issues to investigate.

\section{A BRIEF HISTORY OF KEY ISSUES STUDIES}

Many key issues studies have now been carried out, from Ball and Harris (1982) to the most recent (1995) SIM (USA) survey (Brancheau et al., 1996). An historical summary of 21 major studies has been provided in Table 1 below:

\begin{tabular}{|l|c|l|l|l|l|}
\hline Authors & $\begin{array}{l}\text { Year of } \\
\text { Study }\end{array}$ & Country & $\begin{array}{l}\text { Sample } \\
\text { (Response rate) }\end{array}$ & $\begin{array}{l}\text { Total No. } \\
\text { of Issues }\end{array}$ & Research Method \\
\hline Ball \& Harris & 1982 & U.S.A & $\begin{array}{l}\text { SIM Members } \\
(417 / 1400)\end{array}$ & 18 & Survey \\
\hline Martin & 1982 & U.S.A & $\begin{array}{l}\text { IS Executives } \\
(15 / ? ?)\end{array}$ & 8 & $\begin{array}{l}\text { C.S.F Interviews } \\
\text {-2 Rounds }\end{array}$ \\
\hline $\begin{array}{l}\text { Dickson, Leitheiser, } \\
\text { Wetherbe \& Nechis }\end{array}$ & 1984 & U.S.A & $\begin{array}{l}\text { SIM members } \\
(54 / ? ?)\end{array}$ & 19 & $\begin{array}{l}\text { Four round Delphi } \\
\text { Survey }\end{array}$ \\
\hline Hartog \& Herbert & 1986 & U.S.A & $\begin{array}{l}\text { IS Managers } \\
(63 / 107)\end{array}$ & 21 & Survey and Interviews \\
\hline Brancheau \& Wetherbe & 1987 & U.S.A & $\begin{array}{l}\text { IS \& Gen. Mgrs. } \\
(68 / 180)\end{array}$ & 26 & $\begin{array}{l}\text { Three round Delphi } \\
\text { Survey }\end{array}$ \\
\hline
\end{tabular}




\begin{tabular}{|c|c|c|c|c|c|}
\hline Parker \& Idundun & 1987 & $\begin{array}{l}\text { United } \\
\text { Kingdom }\end{array}$ & $\begin{array}{l}\text { IS Managers } \\
(45 / 100)\end{array}$ & 23 & Survey and Interviews \\
\hline Rao, Huff \& Davis & 1987 & Singapore & $\begin{array}{l}\text { IS Managers } \\
(19 / 105)\end{array}$ & $? ?$ & Survey \\
\hline Davenport \& Buday & 1988 & Europe & $\begin{array}{l}\text { IS Executives } \\
(75 / 2000)\end{array}$ & $? ?$ & Survey \\
\hline Watson & 1988 & Australia & $\begin{array}{l}\text { IS Managers } \\
(48 / 200)\end{array}$ & 26 & $\begin{array}{l}\text { Three round Delphi } \\
\text { Survey }\end{array}$ \\
\hline Moynihan & 1990 & Ireland & $\begin{array}{l}\text { CEO/TT Mgrs. } \\
(49 / ? ?)\end{array}$ & $? ?$ & Structured Interviews \\
\hline $\begin{array}{lll}\text { Caudle, } & \text { Gorr } & \& \\
\text { Newcomer } & & \\
\end{array}$ & 1991 & U.S.A & $\begin{array}{l}\text { PS Mgrs. } \\
(354 / 1054) \\
\end{array}$ & 37 & Survey \\
\hline $\begin{array}{l}\text { Niederman, Brancheau \& } \\
\text { Wetherbe }\end{array}$ & 1991 & U.S.A & $\begin{array}{l}\text { SIM Members } \\
(1 . \quad(104 / 241)\end{array}$ & 25 & $\begin{array}{l}\text { Three round Delphi } \\
\text { Survey }\end{array}$ \\
\hline Watson \& Brancheau & 1991 & $\begin{array}{l}\text { International } \\
\text { comparison }\end{array}$ & $\begin{array}{l}\text { Previous studies } \\
\text { compared }\end{array}$ & 15 & $\begin{array}{l}\text { Descriptive/ } \\
\text { interpretive }\end{array}$ \\
\hline Badri & 1992 & $\begin{array}{l}\text { Gulf Coop'n } \\
\text { Council }\end{array}$ & $\begin{array}{l}\text { IS CEOs } \\
(96 / 120)\end{array}$ & 20 & Survey \\
\hline Clark & 1992 & U.S.A & $\begin{array}{l}\text { IS Executives } \\
(30)\end{array}$ & 6 & Structured Interviews \\
\hline $\begin{array}{l}\text { Doukidis, Smithson \& } \\
\text { Naoum }\end{array}$ & 1992 & Greece & $\begin{array}{l}\text { IS Managers } \\
(40)\end{array}$ & 20 & Personal Interviews \\
\hline $\begin{array}{lll}\text { Galliers, } & \text { Merali } \quad \& \\
\text { Spearing }\end{array}$ & 1992 & $\begin{array}{l}\text { United } \\
\text { Kingdom }\end{array}$ & $\begin{array}{l}\text { Managers (incl. } \\
\text { IS) (98/??) }\end{array}$ & 26 & Survey \\
\hline Pervan & 1992 & Australia & $\begin{array}{l}\text { IS Managers } \\
(1 . \quad(88 / 300)\end{array}$ & 34 & $\begin{array}{l}\text { Three round Delphi } \\
\text { Survey }\end{array}$ \\
\hline Wang \& Turban & 1994 & Taiwan & $\begin{array}{l}\text { IS \& Gen. Mgrs. } \\
(297 / 928)\end{array}$ & 30 & Survey \\
\hline $\begin{array}{l}\text { Davis, Menon, Munday, } \\
\text { Thomson \& Young }\end{array}$ & 1995 & New Zealand & $\begin{array}{l}\text { Various } \\
(118 / 392) \\
\end{array}$ & 23 & $\begin{array}{l}\text { Three round Delphi } \\
\text { Survey }\end{array}$ \\
\hline Kim \& Sato & 1995 & Japan & $\begin{array}{l}\text { IS professionals } \\
(197 / 400)\end{array}$ & 25 & Survey \\
\hline $\begin{array}{lll}\text { Brancheau, Janz \& } \\
\text { Wetherbe }\end{array}$ & 1995 & U.S.A. & $\begin{array}{l}\text { SIM Members } \\
(83 / 217)\end{array}$ & 23 & $\begin{array}{l}\text { Three round Delphi } \\
\text { Survey }\end{array}$ \\
\hline
\end{tabular}

Table 1: A History of Key Issues Studies

The most common research approach used has been the postal survey, either single-round or in three- or fourround Delphi studies. The major US studies have sampled the membership of the Society for Information Management (SIM) whose membership consists of a mix of IS academics and practitioners. Most other studies have obtained opinions from IS managers and/or other non-IS managers. In most cases the organisations sampled have been quite varied in size and industry, and the sample sizes have varied significantly. The studies have generally sought opinions of the major 'key' or 'critical' information systems management issues facing these organisations. One of the most recent studies (Galliers et al., 1994) considers issues as important (they have a significant impact within the organisation), problematic (they are difficult to manage), and critical (they are both important and problematic).

\section{THE KEY ISSUES}

As indicated in Table 1, there are many different IS management issues. While most researchers accept that IS executives must handle many technology management (TM) issues, there is a growing acceptance that there are many strategic management (SM) issues which are equally, if not more, important. Other categories of issues include systems development and data management (SDDM), people management (PM), and end-user computing ( $E U C$ ). A brief discussion of the major categories and issues follows, though it should be pointed out that some of the issues may overlap some categories. These issues have changed over time, but those discussed below are based on the most recent Australian (Pervan, 1994), US (Brancheau et al., 1996), and UK (Galliers et al., 1994) studies. 


\section{Technology Management Issues}

In the 1990s organisations are heavily committed to investment in information and communications technology. The major technology management issues may include:

- building a responsive IT infrastructure (to support applications in the face of rapidly changing technologies and range of applications);

- measuring IS effectiveness and productivity (to justify investment in new technologies);

- improving data integrity and quality assurance (to overcome inconsistencies between different data sources and the lack of controls in IS and user departments);

- developing and managing electronic data interchange (to provide electronic communication with customers and suppliers);

- planning and integrating multi-vendor open systems technologies (in the face of a variety of operating environments and unstable standards);

- integrating data processing, office automation, and telecommunications;

- managing data and document storage;

- planning and managing communications networks (the 'lifeblood' of the 1990s organisation);

- implementing and managing collaborative support systems (to help teams share information and improve their effectiveness); and

- establishing effective disaster recovery capabilities (to guard against downside risks and potential loss of business).

\section{Strategic Management Issues}

Traditionally, the IS function was seen by top management as being primarily a support activity with little impact on the profitability or nature of the business (Doukidis et al., 1991), but this viewpoint is changing in the 1990s. IS strategic planning can help to identify high return applications, gain competitive advantage, improve the IS function, support business strategy, and provide a general framework to guide the activities of the organisation. The major strategic management issues thus may include:

- improving IS strategic planning (to align IS plans with business strategic plans in the face of changing business and technological environments, increasing user involvement);

- developing and implementing an information architecture (to identify major business categories and relationships to business processes, guide applications development, and facilitate better data integration and sharing);

- aligning the IS organisation within the enterprise (which may require a combination of centralised and decentralised structures);

- outsourcing selected information services;

- determining appropriate IS funding levels;

- facilitating and managing business process redesign (where IT may play an increasingly important role); and

- using information systems for competitive advantage (by recognising opportunities through creativity and innovation followed by rapid implementation).

\section{People Management Issues}

Current and future shortages of qualified information systems personnel threaten the IS department's ability to keep up with the information requirements of the organisation and greater business skills are needed to provide a better understanding of these needs. Further, the members of the organisation as a whole (including senior management) need to develop appropriate knowledge and understanding in the use of information systems and technology. The major people management issues thus may include:

- recruiting and developing IS human resources (to overcome shortages, develop career paths, enhance business skills and skills with new technologies and methodologies);

- facilitating organisational learning (in order to make appropriate use of information technologies across the entire organisation);

- educating senior management in relation to IT (to support resource allocation to IT and enhance understanding of the strategic impact of IT); and

- increasing understanding of IS role and contribution (by all members of the organisation). 


\section{Systems Development and Data Management Issues}

In the 1980s the IS discipline was mostly concerned with the problems of systems development and data management (Hartog and Herbert 1986). A growing number of techniques and tools have been developed to improve the productivity and quality of IS development. The major systems and data issues may include:

- improving the effectiveness of software development (to reduce backlogs through new development methods and platforms);

- selecting and integrating packaged applications software (which may cut costs and boost productivity, but may result in integration and maintenance problems);

- making effective use of the data resource (through appropriate database technologies and valuing data as a corporate asset);

- managing the existing portfolio of legacy applications (which may affect integration of new technologies and migrating to new operating environments);

- developing and managing distributed systems (where client-server environments provide problems of consistency of software versions and data, and challenges in project management);

- improving information security and control;

- planning and managing the applications portfolio (and the ever-increasing maintenance problem); and

- planning and using CASE technology (to more effectively support the systems development process).

\section{End-user Computing Issues}

One of the most significant IS challenges is the control of computing by end users who may develop and/or operate systems independently of the IS department (Doukidis et al. 1991). The IS department must balance control with learning and innovation in order to provide support for these end users. These issues may include:

- facilitating and managing end-user computing (by balancing control against the need for slack and clarifying the respective roles of IS and end-users); and

- facilitating/managing executive and decision support systems (to improve decision making by executives and other members of the organisation).

\section{RESEARCH DESIGN}

In order to provide information concerning the key IS management issues, a postal survey of the most senior IS person in the top 500 Australasian organisations was conducted in March/April, 1996. The Bulletin magazine's publication of the 'Top 500' organisations in Australia and New Zealand in 1995 (Jacques, 1995) provided a list (and associated financial and classification data) of the 500 largest organisations by revenue. From the list of identified organisations, a mailing list of the most senior IS person in each organisation was developed by telephone contact to each organisation to identify the name and exact title of the appropriate person. (Personal identification and addressing of postal surveys is a recommended strategy for increasing response rates (Forsgren 1989)). In the course of the development of this mailing list, some organisations were removed because they were either subsidiary to other (larger) organisations on the list which provided the IT management function or because they were just unwilling to participate in such surveys. A final list of 490 'CIOs' (Chief Information Officers) was produced (though some of these CIOs used other titles, including IT Manager, IS Manager, and Director of $[T$ ).

The aim of this study was to identify the key IS management issues for these organisations over the next 3-5 years. The approach taken was similar to the most recent UK study (Galliers et al., 1994) where the respondents were asked to rate both how important and how problematic each issue was for their organisation. A list of 31 issues with an associated paragraph of explanation for each issue was produced from the 25 most critical issues from the last Australian study and any new issues from the most recent US and UK studies. In addition to the brief title for each issue, a paragraph explaining the issue (its 'rationale') was included to ensure that the meaning of each issue was interpreted consistently across all respondents. These 31 issues have been briefly discussed in the previous section and a list of all issues and their rationale is provided as Appendix A.

\section{THE RESULTS OF THE STUDY}

Valid questionnaires were received from 105 of the 490 organisations, representing the full range of the organisations targeted (including the 1st and 497th ranked organisations). Table 2 below shows that these are 
indeed large organisations with revenue, assets and profits measured in the billions of dollars. Table 3 shows the location of company headquarters and the sector to which that organisation's primary activity belongs. The response rate of $21.4 \%$ may be considered reasonable in a postal survey of this nature.

\begin{tabular}{|c|c|c|c|c|}
\hline Variable & $\begin{array}{c}\text { Mean } \\
\mathbf{( \$ b )}\end{array}$ & St. Dev. $\mathbf{( \$ b )}$ & $\begin{array}{c}\text { Min. } \\
\mathbf{( \$ b )}\end{array}$ & $\begin{array}{c}\text { Max. } \\
(\mathbf{\$ b})\end{array}$ \\
\hline Revenue & 1.339 & 4.376 & 0.160 & 18.487 \\
\hline Assets & 1.868 & 2.986 & 0.014 & 30.287 \\
\hline Profit & 0.083 & 0.248 & -0.372 & 1.753 \\
\hline
\end{tabular}

Table 2: Respondent Organisations - Financial Data

\begin{tabular}{|l|c|c|c|c|c|c|c|c|c|}
\hline \multicolumn{1}{|c|}{ Headquarters } & Vic & NSW & SA & Qld & WA & ACT & NT & NZ & Total \\
Sector & & & & & & & & & \\
\hline Resources/Mining & 3 & 3 & 0 & 0 & 1 & 0 & 0 & 0 & $\mathbf{7}$ \\
\hline Retail/Trading & 4 & 6 & 0 & 2 & 1 & 0 & 0 & 0 & $\mathbf{1 3}$ \\
\hline Services & 8 & 7 & 2 & 2 & 2 & 0 & 0 & 0 & $\mathbf{2 1}$ \\
\hline Manufacturing & 14 & 25 & 2 & 1 & 4 & 0 & 0 & 1 & $\mathbf{4 7}$ \\
\hline Government & 5 & 3 & 1 & 3 & 2 & 2 & 1 & 0 & $\mathbf{1 7}$ \\
\hline Total & $\mathbf{3 4}$ & $\mathbf{4 4}$ & $\mathbf{5}$ & $\mathbf{8}$ & $\mathbf{1 0}$ & $\mathbf{2}$ & $\mathbf{1}$ & $\mathbf{1}$ & $\mathbf{1 0 5}$ \\
\hline
\end{tabular}

Table 3: Respondent Organisations - HQ and Sector

As Table 3 above indicates, responses were received from all states and territories and one from New Zealand (a major beer producer). The largest sector represented in the sample (and in the target Top 500 population) was manufacturing (45\%), while major government instrumentalities for energy, water, and transport made up most of the $16 \%$ from the government sector. The two most populous states, New South Wales and Victoria, made up 74\% of the sample, confirming that the majority of company headquarters of large Australian organisations are in Sydney and Melbourne. Chi-squared goodness of fit tests on location of headquarters, rank in the top 500, and industry sector showed the sample to be representative at the $5 \%$ level of significance.

\section{Critical Issues}

As indicated earlier, respondents were asked to rate both how important an issue will be for their organisation over the next 3-5 years, and how problematic the issue might be. These were both rated on a 1 to 10 scale where 1 represented a lowest priority issue and 10 represented a highest priority issue. All respondents provided a score for both on all issues. Before separately examining the important issues, and similarly the problematic issues, the two ratings were combined into an overall rating of the issue. In previous studies, issues were usually assessed on how critical they were for the organisation. This study used the approach of Galliers et al. (1994), where a critical issue was defined as being both important and problematic. Based on this definition, how critical an issue was to the organisation was calculated as the arithmetic mean of the ratings for important and problematic. The ten most critical issues, with their ranking, mean and standard deviation of critical rating, are shown in Table 4 below. A full list showing mean and standard deviation for all 31 issues is provided as Appendix B.

\begin{tabular}{|c|c|c|c|c|}
\hline Rank & ISSUE & $\begin{array}{c}\text { Issue } \\
\text { Category }\end{array}$ & $\begin{array}{c}\text { Mean } \\
\text { Rating }\end{array}$ & $\begin{array}{c}\text { Std. } \\
\text { Dev. }\end{array}$ \\
\hline 1 & Building a responsive IT infrastructure & TM & 7.19 & 1.65 \\
\hline 2 & Planning and managing communications networks & TM & 6.93 & 1.92 \\
\hline 3 & Establishing effective disaster recovery capabilities & TM & 6.88 & 1.66 \\
\hline 4 & Making effective use of the data resource & SDDM & 6.87 & 1.63 \\
\hline 5 & Facilitating organisational learning & PM & 6.86 & 1.59 \\
\hline 6 & Facilitating and managing end user computing & EUC & 6.80 & 1.73 \\
\hline 7 & Educating senior management in relation to IT & PM & 6.73 & 1.96 \\
\hline 8 & Using information systems for competitive advantage & SM & 6.72 & 1.91 \\
\hline 8 & Improving IS strategic planning & SM & 6.72 & 1.91 \\
\hline 10 & Aligning the IS organisation within the enterprise & SM & 6.71 & 2.04 \\
\hline
\end{tabular}

Table 4: The Ten Most Critical Issues 
The relative ranking of issues within the top 10 should not be overly highlighted because their mean ratings range only by 0.48 on a 10-point scale (with a range of only 0.22 between 2 nd and 10th) and the average standard deviation is 1.80 . However, it is interesting to note that each of the five issue categories have one or more issues in this top group. While previous research seemed to indicate that there would be a trend away from technology management for CIOs, this is contradicted by the appearance of IT infrastructure, communications, and disaster recovery (all technology management issues). However, this should come as no surprise in such a rapidly changing technological environment. It is clear that the fundamental role of the $\mathrm{CIO}$ is the provision of a responsive IT infrastructure for the organisation and that communications networks provide the backbone of that infrastructure in the 1990s. This infrastructure can also be assumed to play a critical role in recognising, accessing, and utilising the organisation's data resources (ranked 4th).

People management issues also rank highly, with the issues of organisational learning and educating senior management in IT ranked 5th and 7th, respectively, and end-user computing (which involves similar motivations and contains a significant user training/education component)) ranked 6th. With the advent of desktop computers and distributed computing, larger organisations are beginning to view the non-IS people in the organisation as 'customers' rather than 'users' and to perceive IS as a service function for those customers (Pitt et al., 1995). Further, the IT education of the customers comes through very strongly in these issues, both from an organisational efficiency and effectiveness viewpoint (through increased productivity and reducing applications backlogs - see Brancheau and Brown (1993)), and as a strategy for enhancing the acceptance of IS within the organisation (Moynihan, 1990). An emphasis on supporting and managing organisational learning can lead to significant increases in innovation and productivity from an organisation's IT investment (Henderson and Lentz, 1996).

As indicated in Table 4, some strategic issues also ranked highly (in addition to the fact that some of the technology and people management issues have strategic aspects). Strategic IS planning (SISP) continues to be a major issue, being ranked 9th. It is a key element of IS management and the CIO must lead in the use of formal methods for SISP and encourage good practice within the organisation (Earl, 1993). This can facilitate effective management of other strategic issues such as the alignment of IS within the enterprise (ranked 10th) and identifying opportunities to use IS for competitive advantage (ranked 8 th).

In summary, the most critical issues were revealed to be a mix of technology management issues (IT infrastructure, communications, disaster recovery), strategic management issues (competitive advantage, IS planning, aligning the IS organisation), people management issues (organisational learning, educating senior management in IT), systems development and data management issues (effective use of the data resource), and end-user computing. This reflects the need for a balance of business, technical, and people skills in an IS executive.

\section{Non-Critical Issues}

The issues which were rated and ranked the ten least critical are shown in Table 5 below. Overall, it may be observed from Table 5 that individual technology management and systems development and data management issues are of little concern to the CIO. Five of the ten least critical issues relate to individual information technologies (namely, electronic data interchange, collaborative systems, data/document storage, multi-vendor integration, and CASE) and three relate to specific systems management issues (namely, distributed systems, applications portfolio, and legacy systems). While these systems and technologies are part of the overall infrastructure, it is their overall selection, integration, and management which is of greater concern to the CIO and the organisation.

\begin{tabular}{|c|c|c|c|c|}
\hline Rank & ISSUE & $\begin{array}{c}\text { Issue } \\
\text { Category }\end{array}$ & $\begin{array}{c}\text { Mean } \\
\text { Rating }\end{array}$ & $\begin{array}{c}\text { Std. } \\
\text { Dev. }\end{array}$ \\
\hline 22 & Developing and managing distributed systems & SDDM & 6.16 & 2.35 \\
\hline 23 & Determining appropriate IS funding levels & SM & 5.98 & 2.09 \\
\hline 24 & Developing and managing electronic data interchange & TM & 5.84 & 2.01 \\
\hline 25 & Implementing and managing collaborative systems & TM & 5.73 & 2.17 \\
\hline 26 & Managing data and document storage & TM & 5.64 & 1.91 \\
\hline 27 & Planning and managing the applications portfolio & SDDM & 5.60 & 1.85 \\
\hline 28 & Managing existing portfolio of legacy applications & SDDM & 5.49 & 2.07 \\
\hline 29 & Multi-vendor open systems technologies & TM & 5.41 & 2.27 \\
\hline 30 & Outsourcing selected information services & SM & 5.24 & 2.41 \\
\hline 31 & Planning and using CASE technology & TM & 4.39 & 2.21 \\
\hline
\end{tabular}

Table 5: The Ten Least Critical Issues 
Of the strategic management issues, determining IS funding levels ranks quite low. This may reflect a growing recognition by the senior management of organisations of the value of IT to the organisation and, as a result, less pressure on the CIO in arguing the case for appropriate funding of IT. The major surprise in this list of noncritical issues is IT outsourcing which ranked almost last. It may be that these CIOs believe that, despite the hype, they have (or soon will have) solved their IT outsourcing decision problems. It may also be that this issue is perceived by CIOs as more of a specific IT infrastructure issue and whether a technology or service is provided in-house or outsourced is of little concern as long as it is provided. However, further analysis revealed that the rating of this issue was significantly higher for the 17 government organisations than for the organisations in the other sectors. Political leaders continue to see outsourcing of services (including IT) as a major strategy for smaller government and the CIOs of these organisations recognise that this is unlikely to change in the foreseeable future.

\section{Important vs. Problematic Issues}

In order to clarify the distinction between what is important and what is problematic, the issues which rated, on average, in either the ten most important issues or the ten most problematic issues are summarised in Table 6 below. This also helps to clarify why some issues are more critical than others (because they are important and problematic).

\begin{tabular}{|c|c|c|c|c|}
\hline $\begin{array}{c}\text { Prob. } \\
\text { Rate }\end{array}$ & $\begin{array}{c}\text { Prob. } \\
\text { Rank }\end{array}$ & ISSUE & $\begin{array}{c}\text { Imp. } \\
\text { Rank }\end{array}$ & $\begin{array}{c}\text { Imp. } \\
\text { Rate }\end{array}$ \\
\hline 6.82 & 1 & Building a responsive IT infrastructure & 2 & 7.55 \\
\hline 6.40 & 5 & Planning and managing communications networks & 3 & 7.46 \\
\hline 6.13 & 11 & Establishing effective disaster recovery capabilities & 1 & 7.62 \\
\hline 6.40 & 5 & Making effective use of the data resource & 7 & 7.33 \\
\hline 6.43 & 4 & Facilitating organisational learning & 8 & 7.30 \\
\hline 6.52 & 2 & Facilitating and managing end user computing & 12 & 7.09 \\
\hline 6.33 & 8 & Educating senior management in relation to IT & 11 & 7.13 \\
\hline 6.00 & 18 & Using information systems for competitive advantage & 4 & 7.45 \\
\hline 6.18 & 10 & Improving IS strategic planning & 9 & 7.26 \\
\hline 6.01 & 17 & Aligning the IS organisation within the enterprise & 5 & 7.41 \\
\hline 6.00 & 18 & Developing \& implementing an information architecture & 6 & 7.38 \\
\hline 6.04 & 14 & Improving information security and control & 10 & 7.25 \\
\hline 6.51 & 3 & Increasing understanding of IS role and contribution & 18 & 6.70 \\
\hline 6.26 & 9 & Facilitating and managing business process redesign & 20 & 6.55 \\
\hline
\end{tabular}

Table 6: Important vs. Problematic issues

Table 6 indicates that substantial differences exist between the rankings of problematic and important issues. A rank correlation test of the first 20 important issues with the first 20 problematic issues shows a correlation of only 0.096 . Interestingly, the rankings of the remaining issues (the eleven least important and problematic issues) were almost identical, which implies that the non-critical issues are so because they are perceived to be neither important nor problematic.

Issues which are ranked as far more important than problematic include disaster recovery, competitive advantage, information architecture and IS alignment. This may be because these issues are perceived as important to the organisation (i.e., they can have a significant impact on the organisation), but the CIOs believe that in the future they will have them under control. The growing acceptance and quality of strategic IS planning supports the belief that developing an appropriate information architecture (a direct outcome of SISP), identifying IS for competitive advantage, and properly aligning the IS organisation will be facilitated more easily (Earl, 1993).

On the other hand, issues which are ranked far more problematic than important include end-user computing, IS role and contribution, and business process redesign (BPR). Clearly, these issues are not well managed now and the CIOs of these large organisations believe that they may continue to be difficult issues to manage. The literature on end-user computing (Brancheau and Brown, 1993) and BPR (Earl, 1994; Wastell et al., 1994) both support this concern. The issue concerning the development of an understanding of IS role and contribution is closely associated with the other 'education' issues - facilitating organisational learning and educating senior management in IT (both of which also ranked more problematic than important as shown in Table 6) - and indicates a growing concern for developing knowledge and understanding of IT throughout the organisation. 


\section{Comparison with Previous Australian Studies}

As indicated earlier in this paper, there have been many previous key issues studies but this comparison will focus on the previous Australian key issues studies conducted in 1988 Watson, 1989) and 1992 (Pervan, 1994). Table 7 below summarises the comparative rankings of the key issues from these studies and whether its status as an issue is rising, steady, or falling. For an issue to be included in the comparisons table it had to rank in the top ten issues in either 1988, 1992 or 1996, and the fifteen such issues fall neatly into three groups - the five 'rising stars' (which have risen significantly over the eight years), six issues which have remained fairly steady over that period, and four 'falling stars' (which have fallen significantly over the three studies).

The five 'rising stars' fall into a group of technology infrastucture management issues and a pair of educational issues. The biggest upward movers since 1988 have been IT infrastructure, communications networks, and disaster recovery. In the face of the rapid pace of technological change, the management of the IT infrastructure should be expected to be a key issue and the most fundamental underlying technology is the organisation's communications network which provides the critical linking of members of the organisation with each other and with the outside world. Intranets and the internet can be expected to be major concerns for the CIO for some time to come. In this rapidly changing technological environment it is becoming increasingly important for all levels of the organisation to receive an IT education which will maintain their effective utilisation of the IT resource. This is reflected in the rise of both organisational learning and IT education of senior management as key issues.

\begin{tabular}{|l|c|c|c|c|}
\hline \multicolumn{1}{|c|}{ ISSUE } & $\mathbf{1 9 8 8}$ & $\mathbf{1 9 9 2}$ & $\mathbf{1 9 9 6}$ & Status \\
\hline Building a responsive IT infrastructure & $\mathrm{NI}$ & 2 & 1 & Rising \\
\hline Planning and managing communications networks & 13 & 15 & 2 & Rising \\
\hline Establishing effective disaster recovery capabilities & $\mathrm{NI}$ & 10 & 3 & Rising \\
\hline Making effective use of the data resource & 9 & 4 & 4 & Steady \\
\hline Facilitating organisational learning & 10 & 12 & 5 & Rising \\
\hline Facilitating and managing end user computing & 8 & 11 & 6 & Steady \\
\hline Educating senior management in relation to IT & $\mathrm{NI}$ & $\mathrm{NI}$ & 7 & Rising \\
\hline Using IS for competitive advantage & 7 & 5 & 8 & Steady \\
\hline Improving IS strategic planning & 1 & 1 & 8 & Steady \\
\hline Aligning the IS organisation within the enterprise & 5 & 3 & 10 & Steady \\
\hline Developing \& implementing an information architecture & 3 & 6 & 11 & Steady \\
\hline Improving data integrity and quality assurance & 11 & 7 & 17 & Falling \\
\hline Improving the effectiveness of software development & 4 & 8 & 21 & Falling \\
\hline Increasing understanding of IS role and contribution & 6 & 9 & 14 & Falling \\
\hline Recruiting and developing IS human resources & 2 & $\mathrm{NR}$ & 20 & Falling \\
\hline
\end{tabular}

Table 7: Historical Comparison of Australian Key Issues Studies

(NI = not included in the study; $\mathrm{NR}=$ not ranked in the top 20)

Examination of the 'steady' issues shows that they include the four major strategic management issues of IS for competitive advantage, IS strategic planning, IS organisational alignment, and information architecture. These have been fairly steady (though slipping slightly in rank) and may reflect a growing confidence that these issues are being done better through the use of more formal approaches and a perhaps a better understanding of the relationship between the CIO and CEO (Feeny et al., 1992). Facilitating and managing end-user computing has continued to be (and will probably always be) a fairly critical issue (Brancheau and Brown, 1993). Similarly, making effective use of the data resource will continue to be fairly critical in an environment where a greater variety of data (internal and external to the organisation) on a greater variety of platforms need to be accessed, manipulated, analysed, and presented by and for the user-customers.

Among the 'falling stars', improving dato quality and improving software development effectiveness both may reflect a better attitude to quality and effectiveness in Australian organisations (or at least a perception that this is being achieved), and so a growing confidence among CIOs that these issues are now under control. Similarly, the the fall of understanding IS role and contribution may also reflect better communication between $\mathrm{CIO}$ and the organisation's senior management (Feeny et al., 1992). Finally, the issue of recruiting and developing IS human resources may be associated with a number of changes including greater availability of people with the necessary skills, reliance on the outsourcing of IS services (provided by large and small consulting 
organisations), and technologies which give the end-users greater capacity to develop their own systems and solve many of their own problems.

\section{CONCLUSIONS AND FURTHER RESEARCH}

This paper has presented some results from a study of the key issues facing IS executives in Australasia's largest 500 organisations. The most critical issues are a mix of technology management issues (IT infrastructure, communications, disaster recovery), strategic management issues (competitive advantage, IS planning, aligning the IS organisation), people management issues (organisational learning, educating senior management in IT), systems development and data management issues (effective use of the data resource), and end-user computing. This reflects the need for a balance of business, technical, and people skills in a CIO. Non-critical issues are mostly related to systems development and the individual technologies which must be integrated and managed to ensure a responsive $\mathrm{TT}$ infrastructure.

The study reveals that some issues are much more important than problematic (disaster recovery, competitive advantage, information architecture, and IS alignment), which reflects a growing level of knowledge in handling these issues. Other issues, however, are much more problematic than important (end-user computing, IS role and contribution, and BPR), and this reflects a continuing problem with their effective management.

The differences between this 1996 study and the Australian studies conducted in 1992 (Pervan, 1994) and 1988 (Watson, 1989) show that there is a growing confidence in the CIOs ability to manage the strategic issues, a continuing concern about providing a responsive IT infrastructure (especially communications), and a continuing concern with educating all 'customers' in the organisation, including senior management. On the other hand, system and data quality issues, IS role and contribution, and IS human resources are becoming less critical.

This descriptive survey has its limitations, however, and further explanatory work, which will atempt to answer some of the reasons behing the issues, is planned. A follow-up survey will revisit the issues and collect information from the CIOs concerning various aspects of organisational structure, management style, stage of IT maturity, the external environment, and other factors with a view to identifying factors which may explain why different issues vary in how important, problematic, and critical they are in different organisations. Another follow-up study will be to provide the list of issues to the chief executive officers (CEOs) of these and compare their ratings with the CIOs. Finally, a series of case studies is planned which will involve interviews of a number of the CIOs in the Top 500 organisations to investigate the reasons behind the relative ratings of the different issues.

NOTE: An earlier (and smaller) version of this paper has been accepted for presentation at the 7th Australasian Conference on Information Systems, University of Tasmania, December 1996.

\section{REFERENCES}

Badri, M.A. (1992) “Critical Issues in Information Systems Management: An International Perspective", International Journal of Information Management, 12, 179-191.

Ball, L. and Harris, R. (1982) "SMIS Member: A Membership Analysis", MIS Quarterly, 6, 19-38.

Brancheau, J.C. and Brown, C.V. (1993) "The Management of End-User Computing: Status and Directions", -ACM Computing Surveys, 25, 437-481.

Brancheau, J.C., Janz, B.D. and Wetherbe, J.C. (1996) "Key Issues in Information Systems Management: A Shift Toward Technology Infrastructure", MIS Quarterly, 20, 2, 225-242.

Brancheau, J.C. and Wetherbe, J.C. (1987) "Key Issues in Information Systems Management", MIS Quarterly, $11,23-45$.

Caudle, S.L., Gorr, W.P. and Newcomer, K.E. (1991) "Key Information Systems Management Issues for the Public Sector", MIS Quarterly, 15, 170-188.

Clark, T.D., Jr. (1992) "Corporate Systems Management: An Overview and Research Perspective", Communications of the ACM, 35, 61-75.

Davenport, T. and Buday, R. (1988) "Critical Issues in Information Systems Management in 1988", Index Group.

Davis, J.G., Menon, R., Munday, S.R., Thomson, B.G. and Young, L.W. (1995) "Key Issues in Information Systems Management: A New Zealand Perspective", Proceedings of the PRIISM'95 International Conference, Maui, Hawaii, January 2-3, 187-195.

Dickson, G.W., Leitheiser, R.L., Wetherbe, J.C. and Nechis, M. (1984) "Key Information Systems Issues for the 1980's", MIS Quarterly, 8, 135-159.

Doukidis, G.I., Smithson, S. and Naoum, G. (1992) "Information Systems Management Issues in Greece: Issues and Perceptions", Journal of Strategic Information Systems, 1, 63-75.

Earl, M.J. (1993) Experiences in Strategic Information Systems Planning, MIS Quarterly, 17, 1-24. 
Earl, M.J. (1994) "The New and Old of Business Process Redesign", Journal of Strategic Information Systems, 3, 5-22.

Feeny, D.F., Edwards, B.R. and Simpson, K.M. (1992) "Understanding the CEO/CIO Relationship", MIS Quarterly, 16, 435-448.

Forsgen, R.A. (1989) "Increasing Mail Survey Response Rates: Methods for Small Business Researchers", Journal of Small Business Management, October, 61-66.

Galliers, R.D., Merali, Y. and Spearing, L. (1994) "Coping with Information Technology? How British Executives Perceive the Key Information Systems Management Issues in the Mid-1990s", Journal of Information Technology, 9, 223-238.

Hartog, C. and Herbert, M. (1986) 1985 "Opinion Survey of MIS Managers: Key Issues", MIS Quarterly, 10, $351-360$.

Henderson, J.C. and Lentz, C.M.A. (1996) "Learning, Working, and Innovation: A Case Study in the Insurance Industry", Journal of Management Information Systems, 12, 43-64.

Jacques, B. (1995) "Top 500: Overview of the Year", The Bulletin, December 5, 4-50.

Kim, Y.G. and Sato, O. (1995) "Key Issues in Information Systems Management: A Japanese Perspective", Proceedings of the PRISMM'95 International Conference, Maui, Hawaii, January 2-3, 167-174.

Marin, E.W. (1982) "Critical Success factors of Key MIS/DP Executives", MIS Quarterly, 6, 1-9.

Moynihan, T. (1990) "What Chief Executives and Senior Managers Want from their IT Departments", MIS Quarterly, 14, 15-26.

Niederman, F., Brancheau, J. and Wetherbe (1991) "Information Systems Management Issues for the 1990s", MIS Quarterly, 15, 474-500.

Parker, T. and Idundun, M. (1988) 'Managing Information Systems in 1987: The Top Issues for IS Management in the UK", Journal of Information Technology, 3, 31-42.

Pervan, G.P. (1993) "Results from a Study of Key Issues in Australian IS Management", Proceedings of the 4th Australian Conference on Information Systems, Brisbane, Queensland, September 28-30, 113-128.

Pervan, G.P. (1994) "Information Systems Management: An Australian View of the Key Issues", Australian Journal of Information Systems, 1, 32-44.

Pitt, L.F., Watson, R.T. and Kavan, C.B. (1995) "Service Quality: A Measure of Information Systems Effectiveness", MIS Quarterly, 19, 173-187.

Rao, K.V., Huff, F.P. and Davis, G.B. (1987) "Critical Issues in the Management of Information Systems: A Comparison of Singapore and the USA", Journal of Information Technology, 1, 11-19.

Wang, P. and Turban, E. (1994) "Management Information Systems Issues of the 1990s in the Republic of China: An Industry Analysis", International Journal of Information Management, 14, 25-38.

Wastell, D.G., White, P. and Kawalek, P. (1994) "A Methodology for Business Process Redesign: Experiences and Issues", Journal of Strategic Information Systems, 3, 23-40.

Watson, R.T. (1988) "Key Issues in Information Systems Management: An Australian Perspective - 1988", Australian Computer Journal, 21, 118-129.

Watson, R.T. and Brancheau, J.C. (1991) "Key Issues in Information Systems Management: An International Perspective", Information and Management, 20, 213-223. 
Appendix A: Key Issues Questionnaire

What do you consider to be the most critical IS/IT issues facing your organisation over the next three to five years? You are requested to indicate the general level of importance that issue will have for your organisation and also (separately) how problematic it might be on a day to day level. Please indicate your views by rating each issue on the scale 1 to 10 , where 1 indicates a lowest priority issue and 10 indicates a highest priority issue. The more important/problematic the issue the higher the score. Use the spaces below to assign your ratings. Remember, for each issue give one importance score and one problematic score. Each issue is supported by an associated rationale to clarify its meaning.

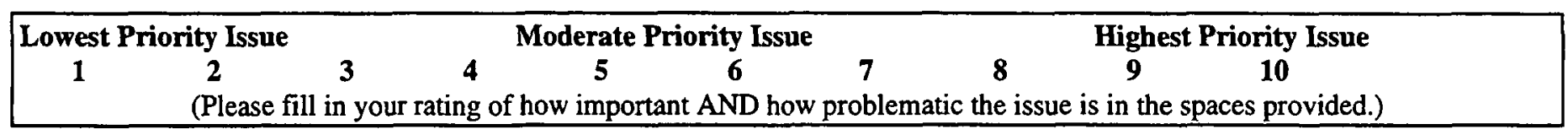

\section{Important Problematic KEY ISSUES AND THEIR RATIONALE}

1.

Developing and implementing an information architecture.

A corporate/global information architecture is needed to identify the major information categories used within an enterprise and their relationships to business processes. It is essential for guiding applications development and facilitating the integration and sharing of data.

2.

Improving information security and control

As organisations increase their dependence on information systems, there is a greater risk from destruction and alteration of data, disclosure to outside sources, and disruption of information services. Tight security controls and fault tolerant information delivery are becoming a necessity.

3.

Facilitating organisational learning

Organisations that prosper will need to make appropriate use of information technologies across their entire enterprise. Business practices and organisational structures will need to be modified in many cases. IS also must demonstrate its own ability to learn and use new technology.

4.

Recruiting, and developing IS human resources

Current and future shortages of qualified information systems personnel threaten the organisation's ability to make effective use of information technology. Career paths need to be clarified. More emphasis needs to be put on developing business skills such as teamwork and leadership and staying current with new technology such as object-oriented and multi-media applications.

5.

Measuring IS effectiveness and productivity

Understanding how IT use impacts the bottom line is crucial for justifying new investment. In addition, measuring the IS organisation's performance is necessary for effective management. Measurement is becoming more important as companies attempt to reduce operating expenses to meet the competition.

6.

Improving data integrity and quality assurance

Mainframe applications, timesharing extracts, and personal computer applications are all used to analyse data and prepare reports. Frequently there are discrepancies among these different data sources due to lack of controls in IS and user departments. Too often computer output is assumed to be accurate. Such assumptions can lead to faulty business decisions.

7.

Improving the effectiveness of software development

The application development backlog remains at unacceptably high levels. Traditional development methods and platforms are no longer satisfactory while new methods and platforms have not yet proven themselves. Sophisticated users are getting impatient. Improved effectiveness will be essential for next-generation applications.

8.

Facilitating/managing executive and decision support systems

Increasing the ability to exploit situations for competitive advantage depends on enhancing the ability of management to "experiment" with decision possibilities. Many other issues also depend on this capability. Decision support tools have long been viewed as a method for introducing modelling tools to executives to improve their decision making, however those efforts have met with mixed success.

9.

Selecting and integrating packaged application software

The changing relationship among costs of hardware, packaged software, and human resources makes managing this aspect of the business critical. Using purchased application software can cut costs, boost productivity, and increase user satisfaction, but it can result in poor integration of systems and serious maintenance problems.

10. Aligning the IS organisation within the enterprise 
The IS organisation's effectiveness in supporting the enterprise's needs is dependent on its organisational location within the enterprise. Appropriate alignment may require a combination of centralised and decentralised structures. Too often IS is not located and structured appropriately.

11 Improving IS strategic planning

It has always been important to align long-range IS plans with strategic business plans. Rapidly changing business environments, increased involvement of end-users, and accelerated technological change underscore the need to continue improving strategic planning skills.

12. Making effective use of the data resource

The organisation's data resource is growing in size, complexity, and value. Despite this, it remains largely unrecognised, inaccessible, and underutilised. IS must develop a climate within its department and throughout the organisation which values the data resources as a corporate asset.

13. Developing and managing electronic data interchange

Electronic communication with customers and suppliers may offer competitive advantage to a company or it may be a requirement for staying in business. IS executives must develop (or adapt to) standard transaction formats, keep current on technology developments, and learn to manage inter-organisational projects.

14. Outsourcing selected information services

The internal information systems organisation no longer has a monopoly. Outside contractors may be able to provide some services more effectively. What services should be outsourced? How should contractor relationships be managed? Fair and objective evaluation techniques are needed which assess both costs and benefits as well as potential risks from loss of control.

15. Planning and integrating multi-vendor open systems technologies

Many companies are moving away from single-vendor proprietary operating environments to vendor-neutral environments based on industry and defacto standards. Due to large investments in legacy systems, carefully planned migration paths are critical. The task is complicated by a still-maturing technology and unstable standards.

16. Determining appropriate IS funding levels

There is no generally accepted way of establishing the level of IS funding relative to the other funding needs of the organisation. This can put both IS and general managers at a disadvantage.

17 Facilitating and managing business process redesign

To remain competitive, many organisations are radically changing the way they do business. IT plays an increasingly important role in this change process by enabling the innovative redesign of core business processes. Much has been learned about $\Pi$ implementation in general which can help facilitate and manage BPR projects.

18 Increasing understanding of IS role and contribution

IS is often viewed as an operational activity with little recognition of its strategic contribution to the organisation. This can result in executive management viewing IS strictly as an overhead expense. Funding can be cut resulting in missed opportunities for using IT to solve important business problems.

19. Integrating data processing, office automation, and telecommunications

The capability now exists to integrate systems that are based on these diverse technologies. As organisations try to integrate their technologies, organisational and managerial problems will need to be solved.

20. Managing data and document storage

Information stored in both electronic and hardcopy form is accumulating at a staggering pace. There is a need to provide for future data and document storage requirements.

21. Planning and managing communications networks

Communication is the lifeblood of the organisation. Using IS for competitive advantage depends heavily on access to appropriate internal and external communication networks. This task is complicated by rapid advances in underlying technology and major structural changes in the communications industry.

22 Managing the existing portfolio of legacy applications

Most organisations have a large investment in their existing applications portfolio. Some "legacy" applications may need to be retired quickly. Others may need to be leveraged for many years before they are replaced. Integrating new technologies and migrating new operating environments can be difficult. Too little is known about managing these problems. 
In many businesses, long-term survival is dependent upon using information systems to gain competitive advantage. Competitive advantage results from recognition of opportunities through creativity and innovation, followed by rapid implementation. These are historical weaknesses of IS.

24.

Developing and managing distributed systems

Client-server applications promise to offer a cost-effective alternative to centralised applications. Unfortunately, they present many challenges including: maintaining consistent software versions; maintaining consistent data; controlling joint development projects with users; and administering large-scale distributed applications.

25. Planning and managing the applications portfolio

The applications portfolio is rapidly increasing in size, complexity, and maintenance cost. Despite the longevity of the maintenance problem, too little is known about managing it effectively.

26. Facilitating and managing end-user computing

The proliferation of end-user computing through personal computers offers the promise of improved productivity but also the dangers of inadequate management control. Information systems management must balance control against the need for slack. Clarification of IS and end-user roles is a necessity.

27. Implementing and managing collaborative support systems

New software is needed to support the reengineered, flat, team-based organisation of the future. Appropriate IT support can help teams share information, lead to faster decision making, and improved team effectiveness. Such support will become even more important in a distributed ubiquitous computing environment.

28. Educating senior management in relation to $\mathbf{I T}$

The education of senior managers in an organisation will lead to more enlightened resource allocation for IS, a more strategic view in IS planning and an understanding of IS's role in the organisation.

29. Planning and using CASE technology

Significant progress has been made automating business functions within organisations; however, a vast productivity gain is possible if the automation process itself is automated. In principle, software systems can provide support for integrating the design efforts of project teams, for standardising representation methods, and for generating code. While this technology is still being refined, providing support for systems development is extraordinarily complex and will require major changes within the IS function.

30. Building a responsive IT infrastructure

Building a technology infrastructure that will support existing applications while remaining responsive to change is a key to longterm enterprise productivity. This task is frustrated by the continuing rapid changes in infrastructure technology and the increasing breadth and depth of applications which need to be supported.

31. Establishing effective disaster recovery capabilities

Down-side risks are increasing daily from the potential loss of business due to a disaster. Effective recovery plans must be in place and tested regularly to ensure losses are minimised As organisational applications grow and become more integrated, the greater the risk becomes. 
Appendix B: Critical Scores for all Key Issues

\begin{tabular}{|c|c|c|c|c|}
\hline Rank & ISSUE & $\begin{array}{c}\text { Issue } \\
\text { Category } \\
\end{array}$ & $\begin{array}{l}\text { Mean } \\
\text { Rating }\end{array}$ & $\begin{array}{l}\text { Std. } \\
\text { Dev. }\end{array}$ \\
\hline 1 & Building a responsive IT infrastructure & TM & 7.19 & 1.65 \\
\hline 2 & Planning and managing communications networks & TM & 6.93 & 1.92 \\
\hline 3 & Establishing effective disaster recovery capabilities & TM & 6.88 & 1.66 \\
\hline 4 & Making effective use of the data resource & SDDM & 6.87 & 1.63 \\
\hline 5 & Facilitating organisational learning & PM & 6.86 & 1.59 \\
\hline 6 & Facilitating and managing end user computing & EUC & 6.80 & 1.73 \\
\hline 7 & Educating senior management in relation to IT & PM & 6.73 & $\overline{1.96}$ \\
\hline 8 & Using information systems for competitive advantage & SM & 6.72 & 1.91 \\
\hline 8 & Improving IS strategic planning & SM & 6.72 & 1.91 \\
\hline 10 & Aligning the IS organisation within the enterprise & SM & 6.71 & 2.04 \\
\hline 11 & Developing and implementing an information architecture & SM & 6.69 & 1.55 \\
\hline 12 & Improving information security and control & SDDM & 6.64 & 1.65 \\
\hline 13 & Measuring IS effectiveness and productivity & TM & 6.63 & 1.71 \\
\hline 14 & Increasing understanding of IS role and contribution & PM & 6.60 & 2.03 \\
\hline 15 & Selecting and integrating packaged applications software & SDDM & 6.55 & 2.03 \\
\hline 16 & Facilitating/managing executive and decision support systems & EUC & 6.46 & $\overline{1.84}$ \\
\hline 17 & Improving data integrity and quality assurance & $\mathrm{TM}$ & 6.41 & 1.82 \\
\hline 18 & Facilitating and managing business process redesign & SM & 6.40 & 2.20 \\
\hline 18 & Integrating data processing, office automation, telecommunications & TM & 6.40 & 1.88 \\
\hline 20 & Recruiting and developing IS human resources & PM & 6.29 & 2.04 \\
\hline 21 & Improving the effectiveness of software development & SDDM & 6.21 & 2.13 \\
\hline 22 & Developing and managing distributed systems & SDDM & 6.16 & 2.35 \\
\hline 23 & Determining appropriate IS funding levels & SM & 5.98 & 2.09 \\
\hline 24 & Developing and managing electronic data interchange & TM & 5.84 & 2.01 \\
\hline 25 & Implementing and managing collaborative systems & $\mathrm{TM}$ & 5.73 & 2.17 \\
\hline 26 & Managing data and document storage & TM & 5.64 & 1.91 \\
\hline 27 & Planning and managing the applications portfolio & SDDM & 5.60 & 1.85 \\
\hline 28 & Managing existing portfolio of legacy applications & SDDM & 5.49 & 2.07 \\
\hline 29 & Multi-vendor open systems technologies & TM & 5.41 & 2.27 \\
\hline 30 & Outsourcing selected information services & SM & 5.24 & 2.41 \\
\hline 31 & Planning and using CASE technology & TM & 4.39 & 2.21 \\
\hline
\end{tabular}

